\title{
Addressing the Dual Challenges of Meeting Demand for Minerals and Sustainable Development
}

\author{
R. Larry Grayson \\ Founding Editor-in-Chief of Minerals, Department of Energy and Mineral Engineering, \\ The Pennsylvania State University, 103-A Hosler, University Park, PA 16823, USA; \\ Tel: +01-814-863-1644; Fax: +01-814-865-3248; E-mail: RLG19@psu.edu
}

Received: 7 October 2010 / Accepted: 12 October 2010 / Published: 12 October 2010

In recent decades, excellent progress has been made globally in finding mineral resources, extracting them efficiently and effectively, dramatically reducing environmental degradation, and preventing adverse health and safety impacts on workers and stakeholders. The industry has realized tremendous advances in technology and applied science; has met changing and more stringent environmental performance criteria; has made remarkable reductions in fatality, illness, and lost-time accident rates; and has connected better than ever before with the communities in which mining, milling, and smelting are housed. A new era focused on continuous improvement in tackling key sustainable development parameters has come and is intensifying [1]. In order to maintain the social licenses needed to enlist broad public support for mining businesses, continued progress must be visible to national, provincial, and local governments as well as the people who live in the areas blessed with the mineral resources that the global economy and growing population will demand.

To be sure, serious challenges against the permitting of mining operations will be made by certain constituents of society in most countries. To counteract these challenges, the industry must continue its progress on all fronts, and more importantly prevent the failures that compromise the sustainable development principles and threaten the social licenses to do business. Numerous global mining companies, for example, are dedicated to working with the citizens in areas where mining investments are likely to occur [2,3], and the majority of the citizens understand the nature of the business and that great progress has been made and will continue. Continuing the progress is the challenge that will require the help of engineering and science researchers working with industry.

The journal seeks contributions in mineral resources and mineralogy; mining science, technology, and engineering; industrial mining; mining equipment; geological materials; metallic materials; and exploration and mining geology. Articles may, for example, present new technologies to enhance discovery of mineral resources, more refined methods to evaluate the feasibility of mineral projects, 
new energy-efficient technologies for mining or processing, significant steps in equipment and mining system automation to help drive greater productivity and higher levels of safety and health, new tools for modeling geological materials and ways to integrate support systems to stabilize post-extraction geologic structures, and better ways to control the interaction of water with minerals that could cause adverse environmental impacts.

Minerals seeks outstanding scientists and engineers to publish reviews, regular research papers and other discourse on issues and challenges related to mineral resources, mining, and mineral processing. Minerals is an open access journal with the advantages of a rapid yet rigorous peer-review system, a high visibility and immediate internet accessibility for published articles. The primary goal of Minerals is publication of state-of-the art research and development articles with reproducible results. A second goal is the broad and quick dissemination of research results to industry, government, and academia, which will further stimulate new research to address persistent issues. The publication costs to authors will be reasonable, thereby ensuring free access by readers. However, the first few issues in 2011 will be published for free.

I am hopeful that Minerals will engage the science and engineering community dedicated to mining in all of its phases in an effort to move forward the important science and technology needed for future progress. Our world, its population, and the natural resources we all enjoy deserve our best efforts, and collectively our contributions to knowledge and progress, made visible by publication in Minerals, will help convince the many constituencies of our industry's sincerity in addressing key issues, and build confidence in them that we can produce the technology necessary to build and maintain good faith over time.

\section{References}

1. International Institute for Environment and Development, World Business Council for Sustainable Development. Breaking New Ground: Mining, Minerals, and Sustainable Development; Earthscan Publications: London, UK, 2002.

2. Newmont Mining. Sustainability. Newmont Mining Corp.: Greenwood Village, CO, USA; Available online: http://newmont.com/sustainability (accessed on 1 October 2010).

3. Rio Tinto. Partnerships. Rio Tinto plc: London, UK; Available online: http://www.riotinto.com/ resources/3608_partnerships.asp (accessed on 1 October 2010).

(C) 2010 by the authors; licensee MDPI, Basel, Switzerland. This article is an open access article distributed under the terms and conditions of the Creative Commons Attribution license (http://creativecommons.org/licenses/by/3.0/). 